着式に適合する事實は少なくとも鞣し中は，後期に如何なる化學 變化が起るとしても，吸着現象が起つて居ると云へる。著者の實 驗の場合クロム吸着量と $\mathrm{Na}_{2} \mathrm{SO}_{4}$ の添加量とが Freundlich 式 $x / m=K C^{1 / n}$ に $1 / n$ を負數とせば適合乙圖式に於て直線が現はれ る事は添加 $\mathrm{Na}_{2} \mathrm{SO}_{4}$ の量或は簡單の䉆, 解離度を省略して考へ れば $\mathrm{SO}_{4}{ }^{\prime \prime}$ イオンの量がクロム吸着量を支配してるると云へよ 了(實驗式は $x / m\left(\% \circ \mathrm{Of}^{2} \mathrm{Or}_{3}\right)=4.596 \cdot \mathrm{C}^{-0.2253} \mathrm{C}=\mathrm{Na}_{2} \mathrm{SO}_{4}$ の濃度 となる)。兩性電解質たるコラーゲンは酸性を呈するクロム鞖液

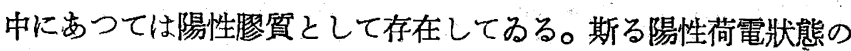
膠質に對し最も强い影響を及ぼするのはゲルと反對符號の除イオ ンである可きは論を俟たない。以上の點よりして著者は此處に於 てクロム鞖しにあつてはコラーゲンに對する陰イオンの一種の 凝結作用が起ると考へる事が出來ると思ふ。そして䩒しとは一つ のキシロゲルなるコラーゲンが (S. F. Seppard, Trans. Faraday Soc., 1933，29，77）ク口ム䩳液中の陰イオンに低り凝結されつ」

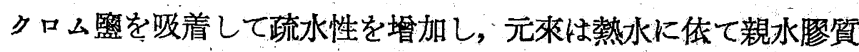
の代表の一つたるゼラチンに變化するコラーゲシが䩳しの進行と 共に次第に耐熱水性となり，逐には水々共に乽沸してb變質しな い迄に疏水性を增加する變化と考へる。郎ち著者はク口ム䕓液中 の陰イオンがコラーグンを凝結せしめる事が一つの䩳しであつ て，斯る凝結作用と共にクロム慜がコラーゲンに吸着して行く のがクロム鞦しであると考へるのである。かつる觀點より寸れば $\mathrm{SO}_{4}{ }^{\prime \prime}$ 又は $\mathrm{Cl}^{\prime}$ イオ.ンの增加と共にク口ム吸着量か減少して行 く原因は，之等陰イオンがク口、錯イオンよりも皮質と結合する 速度がイオンの大きさから云つても電價から云つても勝つてるる 䉆, 先づコラーグンが凝結して疏水性を增すので親水性のクロム 錯イオンが結合し難くなる爲と說明出來よう。
公知の如く疏水ジルが反對符號のイオンで凝結を起し或はゲル 化する場合其の㠜結に要する量はイオンの價數に依り支配され る。又親水ダルが㠜結する場合は水膜の安定性の篇イオン價より はイオンの水和之密接な關係にあると考へられてるるリオトロー ブ順列が重要となるのである。著者の賽驗の場合ではイオンの價 數よりしても, リオトロープ順列よりしても $\mathrm{SO}_{4}{ }^{\prime \prime}$ が $\mathrm{Cl}^{\prime}$ より二 ブーゲンをより强く凝結せしめるであらうと云ふ事が考へられ

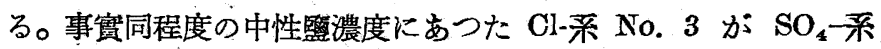
No. 2よりも遥に變質膨化し, $\mathrm{SO}_{4}$-系 No. 1 上り稍膨化の度 が大であつた。換言すると親水性を示めした事は陰イオンの凝結 作用がクロム䫌しに一つの役割をなしてるると云ふ一證左とも云 へよう。

\section{總括}

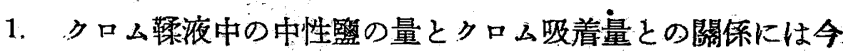
迄一致した結果が與へられてるなかつた。著者はこの原因を論じ， 純粹なる監基性硫酸クロムを以つて䩳しを行ひ $\mathrm{NaCl}, \mathrm{Na}_{2} \mathrm{SO}_{4}$ の添加量の增加は共にク口ム吸着量を減少せしめ, 且兩者間に

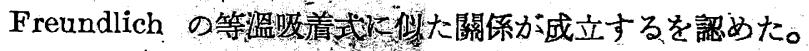

2. クロム鞣液中にあつて陽性想質たるコラーゲンに對しては 䕓夜中の陰イオン 1 種の㠜結作用が行はる可きを論じ, 陰イオン も亦1種の鞂劑なるべきを推論した。

3. 乾燥鞙革のアルコール吸收率に就き述べた。之は革の變質 又は鞖しの良否制定の一指針となる。

本研究中の嘪驗の大部分は著者が 大口製革標式會社在職中䒘於 て行なつたるのであう，附記し、て感謝の意を表する。

\title{
(120) 嗍砂一蟻酸鹽に依る亞鉛の電解定量法
}

\section{谷田, 川 正三}

\section{梗 概}

從來の亞鉛定量法は其の正確度が低い鳳，黃銅の如く多量の亞 鈗を含む合金の分析法としては不適當であつたので，間接法に依 らざるを得なかつたのであるか，不純物をも含む全成分を定量し て殘部を亞鉛とすることは迅速を要件とする工業分析法としては 甚しく迂遠である。

著者は亞鉛電解法につき研究の結果，直接法として十分其の目 的に沿ひ得る方法を得たりで始に其の概要を報告する。

份著者の方法が日本標準規格 (JES) 橫銅青銅中心暨鉛分析方法 に探用されたてとに對して同委員會各位に深き謝意を表する。

\section{I 緒言}

從來行はれてるる亞鉆の定量法の中一般的なものに, 容量法に

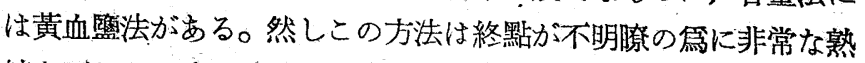
練を要し且つ缸め亞鉛の概量を知る焉に豫㣁試驗をせねばならぬ 不便がある。この不便を澼る婯に W. H. Cone(.J. Am. Chem. Soc., 1927，49，356) は內部指示薬として Diphenylbenzidine を加
へる案を提出してるるが，著者の實驗では混入物の種類に依て終 點が不明膫となり工業分析法として利用出來ない。重量法には焦 性燐酸亞鉛法，燐酸亞鉛アンモニウム法，酸化亞鉛法があるが何 れも相互の結果が甚しく不同である。電解法には醋酸アンモン法 (Classen and Hall: Quantitive analysis by electrolysis (5th Ed) 155) 苛性ソーダ(日本標準规格アルミニウム地金分析法) が あるが前者は電解液の冷却を必要とする不利があり，後者は非常 に高い結果を與へる。又中尾滿三氏（滿鐵中央試瞼所報告第 3 輯

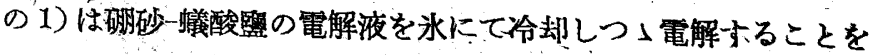
提案してるるか，嘪驗の結果斯くしても何電着亞鉆の所期量は望 まれず海綿狀で剝落し易く失敗に終つた。然しながら著者は本法 に於て電解液に酸性の綗㣫溶液を使用してるる點が興味を感じた ので，之に關し種々研究した結果電解液を冷却せずとす常溫に於 て陽極の迥轉を中止しても纷充分好結果が得られる事を知つたの で妶に其の概要を報告することにする。

\section{II 從來の主なる亞鉛分析法の榆討}


著者法を報告する前に從來の諸方法に就て檢討を加へて見ると 亞鉛の定量法として比較的正確なるものとしては，次の 4 種があ る。（1）酸化亞鉛法，(2) 焦性獜酸亞鉛法，(3) 憐酸亞鉛アンモ ニウ、法，（4）苛性ソーダ法に依る電解定量法

以下順次賽驗の上檢討して見たい。

\section{1. 酸 化 亞 鉛 法}

（1）雷䮦方法 第 1 表の如〈亞鉛（純度既知） $0.4 \mathrm{~g}$ を圓錐 ラスコに採り之に硝酸 (1:1) 15 cc 及硫酸 (1.84) $3 \mathrm{cc}$ を加へて 溶解し加熱して硫酸の白煙を生ずるに至らしめる。次に硫酸 (2: 100） $3 \mathrm{cc}$ を加一て硫酸亞鉛を溶解せしめ微酸性となし水を加一 300 ce となして冷却する。之に硫化水素ガスを約 30４5 分間激 しく通し緩く栓をなした上數時間静置したる後濾紙緎維を大れた る緻密なる濾紙 2 枚にて濾過し硫化水素を含む冷水にて 洗源す

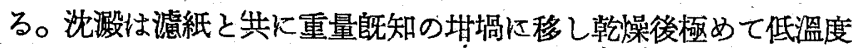
にて濾紙を灰化し，次第に溫度を上昇して $850^{\circ} \sim 900^{\circ} \mathrm{C}$ にて約 30 分間灼熱して酸化亞鉛となしたる後放冷後科量し 亞鉆量を算 出する。

（2）實駼結果．此の方法に從つて得た結果は第1 表の通りで ある。

\begin{tabular}{|c|c|c|c|}
\hline 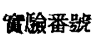 & 亞鉛探取量 (g) & 亞鉛定㽞俌 (g) & 誤琴 (g) \\
\hline 1 & 0.4022 & 0.4040 & +0.0018 \\
\hline 2 & 0.4077 & 0.4090 & +0.0013 \\
\hline 3 & 0.4025 & 04038 & +0.0013 \\
\hline 4 & 0.4053 & 0.4060 & +0.0007 \\
\hline 5 & 0.4011 & 0.4027 & +0.0016 \\
\hline
\end{tabular}

i '上記の方法に依て得る酸化亞鉛中には, 其の灼熱工程中に生ず る硫酸盟を常に残存し平均 $\mathrm{SO}_{\mathrm{s}}$ として $0.13 \%$ を含むことを見出 した。上表揭載の結果が常に高い值を示した一因はこの硫酸聇に 依ると思はれる。

\section{2. 蕉性燐酸亞鉛法}

（1）宽教方法 同じく電解亞鉆 $0.4 \mathrm{~g}$ を圓錐フラスコに探り 之に硝酸 $(1: 1) 15 \mathrm{cc}$ 及硫酸 (1.84) $3 \mathrm{cc}$ を加へ溶解し，加熱し て硫酸の白煙を發生するに至らしめ，冷後水 $150 \mathrm{cc}$.を加硫酸 亞鉛を溶解寸る。之に醞化アンモン $5 \mathrm{~g}$ とアンモ二ア水とを加入 てメチルオレンヂを指示薬として微にアルカリ性となし㿼酸 (1：1）にて中和す。此の溶液を沸黑近く迄加熱した後第二橉酸了 ンモニウム $(10 \%) 40$ c を加へて㩭捧し，20〜25 分間加熱し燐 酸亞鉛アンモニウムが結晶狀沈搌となりて沈降するに至り，濾紙 （例へば東洋 No. 6) を用ひて滤過し溫水にて 盟素の反應なきに 至る迄洗滌する。沈澱は畭燥器中にて幹燥後濾紙より可及的に分 離し，濾紙と共に重量既知の磁製咕佩中に移し，電氣爈にて最初 低溫度で濾紙を灰化し次第に溫度を上景せしめ $900^{\circ} \sim 1000^{\circ} \mathrm{C} K$ て 30 分間灼熱しデシヶーター中にて冷却後焦性燐酸互鉛として 科量し亞鉛含有量を算出する。

（2）赛驗結果 嘪驗結果を示すと第2 表の通りである。

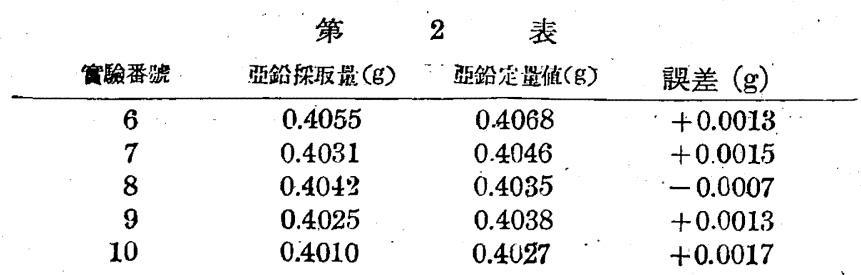

此の場合ぬ第 1 法と同程度の高い結果を與へる。又燐酸亞鉛了 ンモ三ウムの沈澱は滤紙を通り易く絽返し濾過の必要がある。

\section{3. 燐酸亞鉛アンモニウム法}

（1）宽䠝方法 電解亞鉆 $0.4 \mathrm{~g}$ を $3.0 \mathrm{cc}$ ビーカーに探り， “之に硝酸 $(1: 1) 15 \mathrm{cc}$ 硫酸 (184) 3 $\mathrm{cc}$ を加一加熱して硫酸の白煙 を生ずるに至らしめ冷後水 150 cをを加へて生じたる硫酸亞鉛を 溶解する。之に監化アンモン $5 \mathrm{~g}$ を加へメチルオレンヂを指示藥

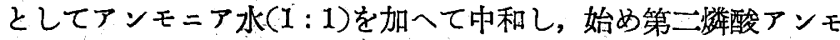
ニウム溶夜(1\%)にて次に水で洗源する。之を $100^{\circ} \sim 105^{\circ} \mathrm{C} に て$ 恒量となる迄乾燥し'冷却後科量して亞鉛量を算出寸る。

（2）渱野結果 實匳結果は次表に示す通りである。

\begin{tabular}{|c|c|c|c|}
\hline 節驗番號 & 晋鉛探反量(g) & '亚鉛定量俌 (y) & 誤差 (g) \\
\hline 11 & 0.4022 & 0.4040 & +0.0018 \\
\hline 12 & .0 .4017 & 0.4024 & +0.0007 \\
\hline $13^{\circ}$ & 0.4077 & 0.4090 . & +0.0013 \\
\hline 14 & 0.4015 & 0.4025 & +0.0010 \\
\hline 15 & 0.4031 & 0.4042 & +0.0011 \\
\hline
\end{tabular}

此の場合も前記墸法程度に高い結果を與へた。、叉燐酸亞鍇アン モニウムの沈澱が滤紙を通り易く繰り返し濾過の必要あることは 第 3 法と同樣である。

\section{4. 菏性ソーダ法に依る電解定量法}

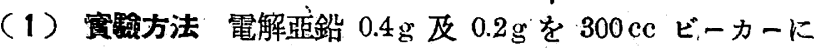
探り前者には硝酸 $(1 ： 1) 15 \mathrm{cc}$ 及硫酸(1.84) $3 \mathrm{cc}$ ，後者には硝酸 (1:1) $10 \mathrm{cc}$ 及硫酸(1.84) $2 \mathrm{ec}$ を加へて溶解し加熱して硫酸の白

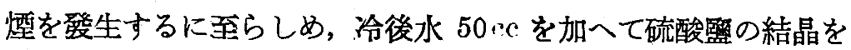
溶解する。次に夰性ソーダ (4\%) $25 \mathrm{cc}$ を加へ液量を約 $150 \mathrm{cc}$ となし銅鍍した圓筒狀白金陰極 (JES 型) と螺狀白金陽極 (JES) とを用ひ空溫 $\left(15^{\circ} \sim 30^{\circ} \mathrm{C}\right)$ にて $1 \mathrm{~A}$ の電流密度にて約 3 時間電 解する, 電解完了後常法汇從ひ電極を科量する。

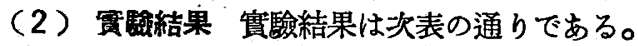

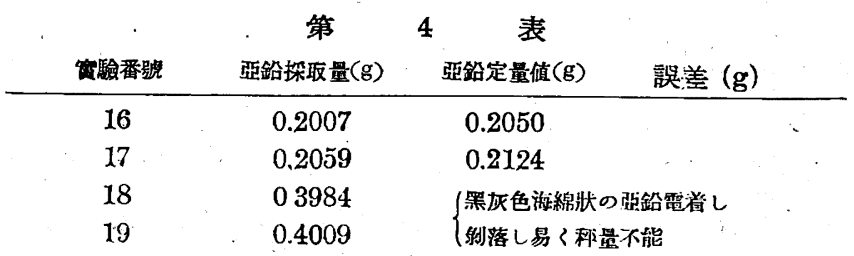

上表に示す如く秤量可能の場合でも少前記諸法に比し箸しく高 い結果を與へる。

\section{5. 上記 4 種の方法に對する考察}

（1）酸化亞鉛法は酸化亞鉛中に $\mathrm{SO}_{3}$ とてて $0.13 \%$ を含有 することは直接定量法の目的から見ると，甚だ大きな數字であつ てそれのみにて既に標淮分析法としての價值に乏しい。

(2)，燐酸互鉛アンモニウムの沈澱を濾過する操作を含む前記 2 支 3 の方法は沈澱の漏り易きことから不便が多い。

（3）尚以上の 3 方法仁就き 10 名の分析員の分析結果の最大 最小の差を比較して見ると第 6 表 k示す通り非常に大きい。

從つて 3 方法は分析者が同一人である場合は，既記の如き程度 の誤差であるが分析者を昷にする時, 非常に大きな誤差を生ずる 
ことがわかる。

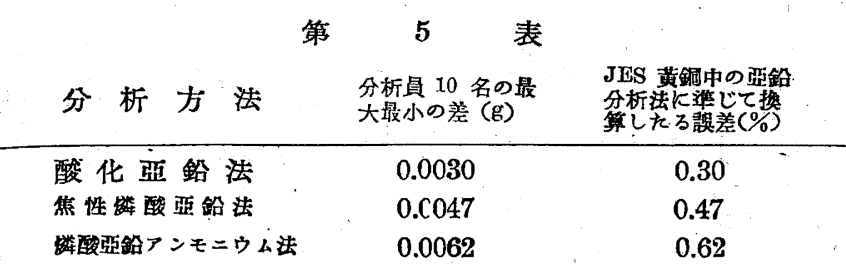

（4）苛性ソーダ法に依る亞鉆の電解定量法は第 5 表に示寸如 く，甚だしく高結果である。本法はアルミニウム地金中の亞鉈定 量法として日本標準規格分析法に探用されてるるが，アルミニウ ム地金のように亞鉛の含量が少ない場合は影響はないが，不正確 な本法が探用されてるることは誤解を招き易いから將來改言され るであらう。

\section{III硼砂-蟻酸㯺に依る亞鉛の電解定量法}

亞鉛の電解定量法はアルカリ性の電解液では前述の通り高結果 を示すか，中尾満三氏は次の方法に從つて高結果を得たと報告し てるる。その概要は純亞鉛の一定量を採り硫酸照とし之に硼砂及

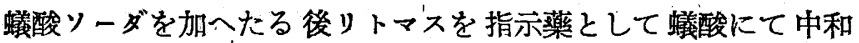
し, 更に其の少過剩を加へた後水で稀釋しビーカーを氷で冷却し つつ銅鍍した白金陰極（フィッシャー氏）を用ひ $5 \mathrm{~V}, 0.9 \mathrm{~A}$ Kて白 金陽極を回轉しつ」電解する。著者は此の方法に從つたが既記の 通り，失敗に終つた。依て次表に示す通り種々研究して見た。郎ち

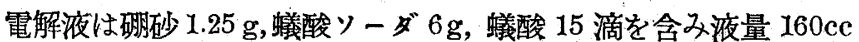
のものを氷で泠却し陽極を每分 300ー400包の割に包轉しつ」電 解した。電解液の $\mathrm{pH}$ は測定の結果 4.3である。

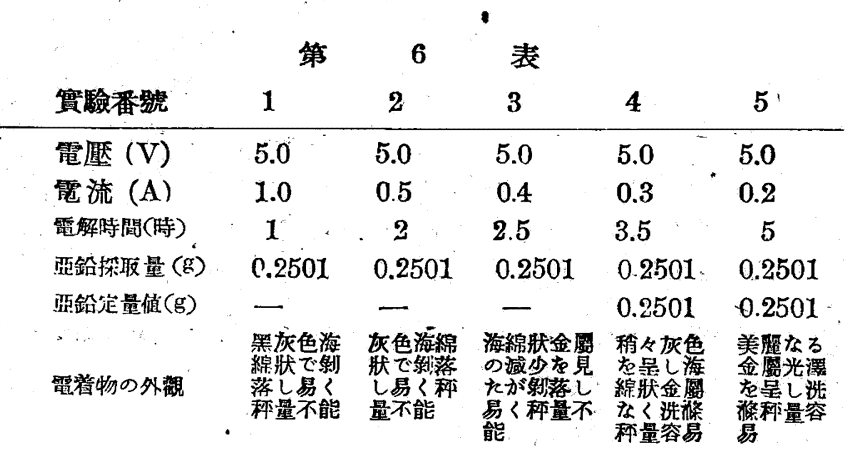

上記の如く實驗番號 4 に至つて漸く正確なる結果を得た。然し 氷にて冷却する事及び四轉する事ば完全なる電解裝置を必要と寸 るのみならず操作も複雜になるから，兩者を中止することにして 他は實驗番號 5 の條件の下に䐝驗して見た。其の結果は第 7 表に 示寸通りである。

\begin{tabular}{|c|c|c|c|c|}
\hline 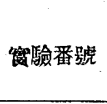 & $\begin{array}{l}\text { 留鉛採取 } \\
\text { 量 }(\mathrm{g}) \\
\end{array}$ & $\begin{array}{l}\text { 亞敛定量 } \\
\text { 価 (g) }\end{array}$ & 諤差(g) & 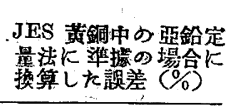 \\
\hline 1 & 0.3966 & 0.3970 & +0.0004 & +0.04 \\
\hline 2 & 0.4044 & 0.4048 & +0.0004 & +0.04 \\
\hline 3 & 0.4080 & 0.4080 & \pm 0.0000 & \pm 0.00 \\
\hline 4 & 0.4036 & 0.4038 & +0.0002 & +0.02 \\
\hline 5 & 1.0008 & 1.0010 & +0.0002 & +0.01 \\
\hline 6 & 1.0005 & 1.0009 & +0.0004 & +0.02 \\
\hline
\end{tabular}

上表に示寸如く黄銅中の亞鉛定量法として淽足なる結果を得 た。尚亞鉆の量が $3 \mathrm{~g}$ 以上の場合の電解は電着に困難があり, 電

解耧液の $\mathrm{pH}$ は 1.8 3.2 程度に增加してるた。

次に析出亞鉆量と電解時間との關係を示すと次圖の樣になる。

第 1 圖

（严鉛探取量 $0.4000 \mathrm{~g}$ )

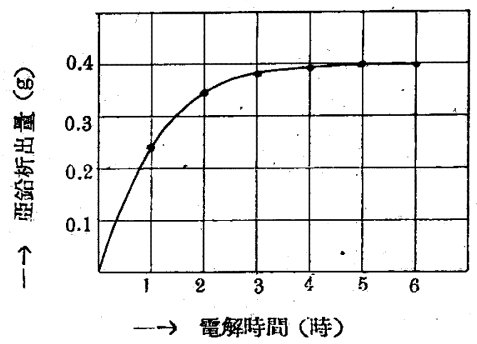

圆に示す如く電解時間 は 6 時間で充分であ る。

電解液調製の際硼砂蟻 酸ソーダの結晶を加へる 事は嗍砂の難溶性に因る 不便が多い、故溶液を作つ て置いて加へると便利て ある。この溶液の保存性 に就ては，念の鴬調製後 1 ケ月後のすのを加へて試驗してみたが 新鮮なるるのと全く同一の結果を與へた。從つて電解液に加ふる 硼砂一蟻酸ソ - ダ溶液は, 水 $1 l$ 中心硼砂 $15 \mathrm{~g}$, 蟻酸ソーダ $75 \mathrm{~g}$ を含有せしめた溶夜 $80 \mathrm{cc}$ を探ることにした。次に電解夜の溫度 の點であるが，之は $30^{\circ} \mathrm{C}$ 以下なればよい。特に氷で领却する必 要はない。

\section{IV 黃銅中の亞鉛電解定量法}

上記蕒驗に基いて著者は黄銅中の亞鉛直接定量法を次の如く提 案したい。

黃銅 $1 \mathrm{~g}$ を $300 \mathrm{cc}$ ビーカーに科取し确酸 (1:1) $15 \mathrm{cc}$ を加 一時計血にて覆ひ溶解後硫酸(1.84)5 cc を加へ蒸發して硫酸の白 煙を發生せしめ過剩の硫酸を殘したる儘冷却する。之に水 $50 \mathrm{cc}$

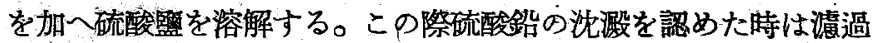
乙硫酸(1：100)で充分泆涤する。淮液に硝酸 (1.42) $3 \mathrm{cc}$ を加一 圓筒狀白金陰極 (JES 型) 及螺狀白金陽極 (JES 型) を用る 0.5 A - 1.0 A Kて銅及鉆を電解分難し電解殘液を蒸墢して硫酸 の白煙の發生を認むるに至らしめる。之に水 $150 \mathrm{cc}$ を加一硫化水 素ガスを通じ能和せしめ濾過し，硫化水素を飽和したる硫酸 (2:

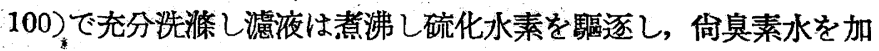
へて硫化水素を分解し再び揞沸して過剩のブロムを追出すとの 操作が不充分である時は $\mathrm{S}^{\prime \prime}$ が殘存し次の操作に於て生成する硫 化亞鉛中に硫化ニッケルを混合し易いから注意を要する)。次にア ンモニアにて中和し之に蟻酸 (90\%) $23 \mathrm{cc}$ を加へ加熱して沸騰 するに至つて硫化水素を激しく通じつ」冷却後清過し，硫化水素

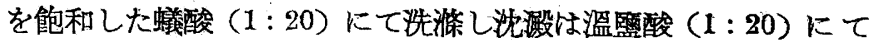
溶解し硫酸 (1.84) 3cc を加へ硫酸の白煙の發生止む迄加熱す る。冷後水 $50 \mathrm{cc}$ に溶解し之を電解ビーカーに移し唧砂蛘酸》 一ダ溶液(前項參照) $80 \mathrm{ce}$ を加へ，この際生じた亞鍇の沈澱を溶 解する䉆繒酸 $(90 \%) 0.7 \mathrm{cc}$ を加へ，液量を $160 \mathrm{ce}$ に稀釋した後 銅鍍し大圓筒狀白金陰極 (JES 型) 及螺狀白金陽極 (JES型) 々 を用ひ，2 箇の牛圓形時計血にて覆ひ室溫に 於て $0.2 \mathrm{~A}$ の䉓流 密度にて電解し, 約 6 時間後時計皿の下面並にビーカーの內壁及 電極の柄の液面に露出した部分を水洗し電解液面を $5 \mathrm{~mm}$ 上らし め, 更に 30 分間電解を續け陰極の柄の新に液中に浸された部分 に最早亞鉛の電着を認めなくなつてから，電流を切ることなく水 洗しつ」電極を引上げ初めは水にて次にアルコールにて洗潫し， 五酸化燐を入れたるデシヶーター中にて 30 分間以上乾燥の上称 量して亞鉆の含有量を定める。

黃銅中の全成分（互鉈を除く）を定量し，その合計を100より 差引きたる殘部を亞鉛とする所謂間接法又は差數法と著者の直挍 
法との比較結果を示すと第 8 表に示す通りである。

\begin{tabular}{|c|c|c|c|}
\hline \multirow[b]{2}{*}{ 驗番號 } & \multicolumn{2}{|r|}{8 表 } & \multirow[b]{2}{*}{ 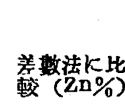 } \\
\hline & $\begin{array}{l}\text { 善整洼\%) } \\
\text { (20) }\end{array}$ & 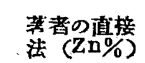 & \\
\hline$x$ & 29.51 & 29.54 & +0.03 \\
\hline-2 & 29.50 & 29.52 & +0.02 \\
\hline 3 & 29.52 & 29.52 & \pm 0.00 \\
\hline 4 & 29.50 & 29.52 & +0.02 \\
\hline
\end{tabular}

上表に示寸如く約 $0.02 \%$ 高結果であるが工業分析法として所 期の目的に沿ひ得る方法である事がわかつた。

所要日數は差數法の約 $1 / 3$ である。

$\mathbf{v}$ 摘 要
（1）亞鉛の正確なる分析法を決定し從來探用し得なかつた迅 速なる黃銅中の亞鈶の直接定量法を得儿として研究に着手した。

（2）從來の亞鉛分析方法中比較的正確とされてるる酸化亞鉛 法, 焦性燐酸亞鉛法, 蹸酸亞鉛アンモニウム法及苛性ソーダに依 る電解法につき检討したが，直接法としての價值に忌い事を知 つた。

（3）硼砂-蜬酸ソ一ダ溶液を電解夜とする電解定量法を研究 の結果希望する分析法を得た。結果は差數法より約 $0.02 \%$ 高く (許容差冈) 所要日数は差數法の約 $1 / 3$ である。

（4）亚鉆の電解定量法は種々發表されてるるが，比較的良法 とされてるる醋酸アンモン法及菏性ソーダ法でも $0.2 \mathrm{~g}$ 以上の電 着が困難であるが本法は $1 \mathrm{~g}$ 迄電着容易で結果良好である。

（高松高等商業學校商品寡驗室）（昭和 15 年 3 月 4 日受理）

\section{(121) 木 蠟二鹽基 酸 の 組 成に就て}

\section{椎 名 七 郎}

\section{粕言}

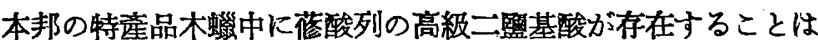
早くより知られた所であり，木蠟力゙他の脂肪に比して其の組織緻 密堅勒なるは主として二监基酸の存在に依るとは，辻本氏（東工 試，昭和 5 , 第 25 回，第 4 號，1) の發表する所である。而して

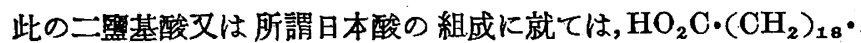
$\mathrm{CO}_{2} \mathrm{H}, \mathrm{HO}_{2} \mathrm{C} \cdot\left(\mathrm{CH}_{2}\right)_{19} \cdot \mathrm{CO}_{2} \mathrm{H}, \mathrm{HO}_{2} \mathrm{C} \cdot\left(\mathrm{CH}_{2}\right)_{20} \cdot \mathrm{CO}_{2} \mathrm{H}$ 又は $\mathrm{HO}_{2} \mathrm{C} \cdot\left(\mathrm{CH}_{2}\right)_{21} \cdot \mathrm{CO}_{2} \mathrm{H}$ 等の報告あることは著者(本誌，昭和 12 ， 40, 706）が暴に記す所であり，未だ涣定的のものと認め難い。 著者の研究は其の組成決定の爲であり，木蠟脂肪酸中には二 䣨基酸として主に $\mathrm{HO}_{2} \mathrm{C} \cdot\left(\mathrm{CH}_{2}\right)_{20} \cdot \mathrm{CO}_{2} \mathrm{H}$ が存在し $\mathrm{HO}_{2} \mathrm{C}$ ・ $\left(\mathrm{CH}_{2}\right)_{18} \cdot \mathrm{CO}_{2} \mathrm{H}$ 。亦存在することを報告する。

\section{試·料 木 蝜}

二監基酸を分離するに原料として使用せる木蠟は，熊本市，肥 後製蠟株式會社の製品余印生蠟にして, 原料庫に渶 3 年間貼藏せ

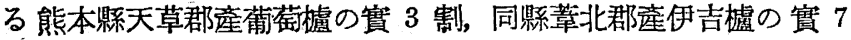
割を以て昭和 13 年 12 月製造せるもので核油を含まざるすので ある。

\begin{tabular}{|c|c|c|c|}
\hline \multicolumn{2}{|c|}{ 試料木䗻の特數 } & ヘーナー貨 & 94.74 \\
\hline 重 $\left(d_{4}^{100}\right)$ & 0.8569 & 不䶨化物 & $0.60 \%$ \\
\hline 點 & $48.5 \sim 49.5^{\circ} \mathrm{C}$ & \multicolumn{2}{|c|}{ 試料木蝮脂肪酸の特数 } \\
\hline 熘 & 20.5 & 融＼cjkstart點 & $55 \sim 56^{\circ} \mathrm{C}$ \\
\hline 化僨 & 208.5 & 中和價 & 214.2 \\
\hline 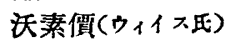 & 12.5 & 沃素價(ウィイス氏 & 13.1 \\
\hline
\end{tabular}

木蠟より二鹽基酸の取分

木蠟はアルコリーゼにより木蠟脂肪酸のメチルエステルとし，

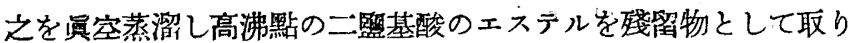
噞化の後遊離脂肪酸とし，更に不油エーテルにて處理し殘存せる

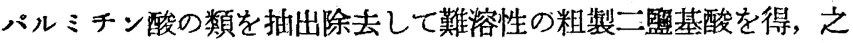
をエチルエステルにし再絬晶により精製した。
アルコリーゼは木蠟に，木蠟の 1.5 倍のメチルアルコール（2 \%の旈酸を含む) 本びメチルアルコールの牛量に當るべンゾール を加へ1夜沸騰せしめ木蠟の 93〜 91\%．に當るエステルを得た。 此のエステルは約 $24^{\circ} \mathrm{O}$ で溶け夏期は液體である。

木蠟脂肪酸のメチルエステル眞空蒸溜は約 $1 \mathrm{~mm}$ にて行ひ沸點 $166 \sim 170^{\circ} \mathrm{C}$ にて約 $80 \%$ を溜出せしめ其の大部分は $167^{\circ} \mathrm{C}$ (油浴 196〜 197 C) にて溜出しだ。

蒸溜殘留物は鹼化の後酸にて分解して遊離脂肪酸とし，次に》 クスレー抽出器にて石油エーテルを以て處理し難溶性の二笽基酸 を得た。此の粗製二盬基酸は褐色にして約 10. 万 $107^{\circ} \mathrm{C}$ で熔融す る。其の熔融して塊となれるものは脆い。メチルエステル $1 \mathrm{~kg}$ より $44 \mathrm{~g}$ の收量である。

侗木蠟中の不噞化物はメチルエステルの買空蒸溜或は遊離䑚肪 酸の不油エーテル處理中に除去されるすのと認められる。

粗製二留基酸は $3 \%$ の硫酸を含む純アルコールにて乽沸してェ チルエステルとし其の結晶は石油エーテルに溶かし骨炭にて脱色

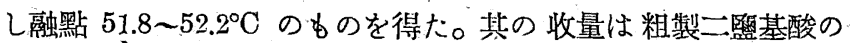

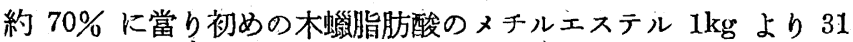
g を得た。

二笽基酸のエチルエステルはアルコールよりよく結晶し且其の 同族體の融點の差は遊離酸の融點の差よりも大であつて精製に便 なるが故粗製二盤基酸は特にェチルェステルとしアルコールによ る再結晶を行ひ精製する事とした。

此の精製により融點 $59^{\circ} \mathrm{C}$ 附近の結晶を得, 其の母夜よりは融 點, $49^{\circ} \mathrm{C}$ 附近の結晶を回收した。其の量前者は $13 \mathrm{~g}$, 後者は $15 \mathrm{~g}$. で脫色後の粗製エチルェステル $31 \mathrm{~g}$ に對し夫々 $42 \%, 49 \%$ の收 量である。

融點 $59^{\circ} \mathrm{C}$ 附近の木蠟脂肪酸のエチルエステルは之を熔融して 放冷せしめる時よく結晶して霜狀となる。然し再結晶に於て佾不 純物が多く融熙 $58^{\circ} \mathrm{C}$ に達せざるものは凝固して餅狀となり結晶 する事がない。融點 $49^{\circ} \mathrm{C}$ 附近のものは熔融狀態より凝固する時。 